\title{
Tipologi Penindakan Kejahatan Korporasi Dalam Korupsi Dana Bantuan Pandemi Covid-19
}

\author{
Michelle Kristina
}

Universitas Surabaya, michellekristina1992@gmail.com

\begin{abstract}
The development of human life nowadays cannot be separated from various aspects such as economy, politics, and technology, including the impact of the coronavirus outbreak (Covid-19 or SARS-CoV-2) which emerged at the end of 2019. Responding to this Covid-19 pandemic outbreak In Indonesia, the government has issued various policies as measures to prevent and handle the spread of Covid-19. One of these policies is to limit community activities. These restrictions have implications for the fulfilment of the economic needs of the affected communities. Responding to the urgency of this community's economic situation, the government held a social assistance program as a measure to ease the community's economic burden. However, the procurement of the program was used as a chance for corruption involving the Ministry of Social Affairs and corporations as the winning bidders. This study uses a qualitative methodology with a normative juridical approach and literature. The approach is carried out by conducting a juridical analysis based on a case approach. The results of the study show that the corporations involved cannot be separated from corporate responsibility. However, the criminal liability process against the corporation is deemed not to reflect justice for the current situation of Indonesia is experiencing. The crime was not carried out in a normal situation but in a situation when Indonesia was trying hard to overcome the urgent situation, the Covid-19 pandemic. Corporate crimes committed by taking advantage of the pandemic situation are deemed necessary to prioritize special action or the weight of criminal acts committed by corporations. The weighting of criminal sanction is the right step as a law enforcement process for corporate crimes during the pandemic.
\end{abstract}

Keywords: Corruption; Corporate Sanction; Covid-19

\section{Jurnal}

YUSTIKA

Media Hukum dan Keadilan Fakultas Hukum Universitas Surabaya Vol. 24 No. 01, July 2021

E-ISSN: 2655-7479

\begin{abstract}
Abstrak
Perkembangan kehidupan manusia saat ini tidak dapat dilepaskan dari berbagai aspek seperti ekonomi, politik, dan teknologi, termasuk dampak dari wabah virus corona (Covid-19 atau SARS-CoV-2) yang muncul pada akhir tahun 2019. Menyikapi wabah pandemi Covid-19 di Indonesia, pemerintah telah mengeluarkan berbagai kebijakan sebagai langkah pencegahan dan penanganan penyebaran Covid-19. Salah satu kebijakan tersebut adalah membatasi aktivitas masyarakat. Pembatasan tersebut berimplikasi pada pemenuhan kebutuhan ekonomi masyarakat yang terdampak. Menyikapi urgensi situasi ekonomi masyarakat, pemerintah pun menggelar program bantuan sosial sebagai langkah meringankan beban ekonomi masyarakat. Namun, pengadaan program tersebut justru dijadikan peluang akan adanya korupsi yang melibatkan antara Kementerian Sosial dengan para korporasi sebagai pemenang tender. Penelitian ini menggunakan metodologi kualitatif dengan pendekatan yuridis normatif dan
\end{abstract}


kepustakaan. Pendekatan dilakukan dengan melakukan analisis yuridis berdasarkan pendekatan kasus. Hasil penelitian menunjukkan bahwa korporasi yang terlibat tidak lepas dari tanggung jawab korporasi dan pengurus. Namun, proses pertanggungjawaban pidana terhadap korporasi tersebut dinilai belum mencerminkan keadilan atas situasi yang dialami Indonesia saat ini. Tindak pidana tersebut tidak dilakukan dalam situasi normal tetapi dalam situasi ketika Indonesia berusaha keras untuk mengatasi situasi yang mendesak yaitu pandemi Covid-19. Kejahatan korporasi yang dilakukan dengan memanfaatkan situasi pandemi dipandang perlu dengan mengutamakan tindakan khusus atas beratnya tindak pidana yang dilakukan korporasi. Pemberatan sanksi pidana merupakan langkah yang tepat sebagai proses penegakan hukum terhadap kejahatan korporasi di masa pandemi.

Kata kunci: Korupsi; Sanksi korporasi; Covid-19

Jurnal Yustika Vol.24 No. 01, Jul 2021

Halaman 12 Tipologi Penindakan Kejahatan Korporasi Dalam Korupsi Dana Bantuan Pandemi Covid-19

Michelle Kristina

\section{Pendahuluan}

Keberadaan korporasi telah banyak memberikan kontribusi dalam memenuhi kebutuhan hidup manusia, contohnya saja dalam bidang ekonomi dengan menciptakan lapangan kerja maupun dari segi pemasukan bagi negara berupa pajak, namun disisi yang lain, perkembangan konsep mengenai korporasi ini juga diikuti dengan semakin berkembangnya kejahatan yang dapat dilakukan dengan menggunakan korporasi atau disebut pula sebagai kejahatan korporasi. Hal ini tidak dapat dilepaskan dari sifat dasar yang dimiliki oleh korporasi yaitu selalu mencari keuntungan. Korporasi dalam proses mencari keuntungan tersebut dapat melakukan segala cara agar keuntungan yang korporasi dapatkan semakin besar atau disebut sebagai anomie of success yaitu sukses tanpa aturan (Yunara, 2005). Akhirnya timbul kejahatan dibidang korporasi sebagai modern crimes in economy (Budianto, 2013).

Korporasi merupakan sebuah istilah yang biasa digunakan untuk menyebut badan hukum (rechtpersoon). Pengertian tentang korporasi merupakan hasil dari konsep pemahaman tentang subyek dalam bidang hukum (Hikmawati, 2017). Subyek hukum adalah manusia atau segala sesuatu oleh hukum diakui sebagai pemilik hak dan kewajiban yang dapat dimintakan pertanggungjawaban (Setiyono, 2005). Pemahaman tersebut mengakibatkan subyek hukum dapat dibagi menjadi dua yaitu natuurlijkpersoon atau manusia dan rechtspersoon atau badan hukum.

Pengaturan korporasi sebagai subyek hukum pidana dapat dilihat dalam berbagai macam peraturan perundang-undangan di luar Kitab Undang-Undang Hukum Pidana (KUHP). Salah satunya adalah Undang-Undang Republik Indonesia Nomor 31 tahun 1999 tentang Pemberantasan Tindak Pidana Korupsi jo. Undang-Undang Republik Indonesia Nomor 20 tahun 2001 tentang Perubahan atas Undang-Undang Republik Indonesia Nomor 31 tahun 1999 tentang Pemberantasan Tindak Pidana Korupsi (selanjutnya disebut sebagai UU Pemberantasan TPK). Pasal 1 angka 3 UU Pemberantasan TPK menyatakan bahwa subyek hukum yang termasuk dalam ruang lingkup 'setiap orang' adalah natuurlijkpersoon dan rechtspersoon.

Adanya pengaturan mengenai korporasi dalam UU Pemberantasan TPK menunjukan bahwa korporasi dapat melakukan kejahatan yang kemudian dikenal sebagai kejahatan korporasi (Satria, 2018). Adapun dimensi kriminal kejahatan korporasi di Indonesia terus berkembang seiring dengan perkembangan perekonomian nasional dan internasional. Dimensi ini terpolakan dalam bentuk-bentuk seperti, defrauding stockholders, defrauding the public, defrauding the government, endangering the public welfare, endangering employees, and illegal 
Jurnal Yustika

Vol.24 No. 01, Jul 2021

Halaman I 3

Tipologi

Penindakan

Kejahatan

Korporasi Dalam

Korupsi Dana Bantuan Pandemi Covid-19

Michelle Kristina intervention in the political process (Hatrik, 1996). Luasnya dimensi kejahatan korporasi berbanding lurus pula dengan besarnya kerugian yang dapat ditimbulkan bila dibandingkan dengan jenis kejahatan konvensional seperti jenis-jenis kejahatan yang diatur dalam KUHP (Prasetyo et al., 2017). Kerugian yang ditimbulkan oleh kejahatan korporasi berdampak luas tidak hanya di bidang ekonomi saja melainkan juga dapat berdampak sampai pada kerugian nyawa jika tidak segera ditindak lanjuti dengan penanganan dan pencegahan yang tepat (Burhanudin, 2013).

Hal tersebut yang menyebabkan perlu adanya pengaturan mengenai Kejahatan Korporasi (corporate crime). Kejahatan korporasi merupakan tindak pidana yang dilakukan oleh pengurus korporasi untuk kepentingan korporasi atau tindak pidana yang dilakukan oleh korporasi itu sendiri (offences committed by corporate officials for their corporation or the offences of the corporation itself) (Ali, 2013). Adanya konsep kepelakuan fungsional (functioneel daderschap) sebagai karya interpretasi kehakiman berpendapat bahwa tindak pidana yang dilakukan oleh korporasi sebagai perbuatan dari subyek hukum yang berbuat dan menghasilkan perbuatan fungsional atas korporasi (Sahetapy, 1994).

Berangkat dari pemahaman tersebut, korporasi dapat melakukan kejahatan berdasarkan konsep kepelakuan fungsional (functioneel daderschap). Ada 3 (tiga) tipe kejahatan korporasi (Ali, 2008), yaitu: (1) Crimes for corporation; (2) Crimes against corporation; dan (3) Criminal corporation. Crimes for corporation merupakan sebutan lain dari kejahatan korporasi. Dalam hal ini dapat dikatakan bahwa kejahatan korporasi dilakukan untuk kepentingan korporasi dan bukan sebaliknya. Crimes for corporation menempatkan korporasi sebagai pelaku tindak pidana karena korporasi berada sebagai pihak yang diuntungkan dalam tindak pidana korporasi tersebut.

Kejahatan terhadap korporasi (crimes against corporations), yang sering dinamakan dengan employee crimes, merupakan kejahatan yang dilakukan oleh para karyawan atau pekerja terhadap korporasi. Misalnya penggelapan dana perusahaan oleh pejabat atau karyawan perusahaan tersebut. Crimes against corporation menempatkan korporasi sebagai korban, artinya tindak pidana yang dilakukan tersebut melawan korporasi atau merugikan korporasi. Sedangkan criminal corporations adalah korporasi yang sengaja dibentuk dan dikendalikan untuk melakukan kejahatan. Kedudukan korporasi dalam criminal corporation hanyalah sebagai sarana melakukan kejahatan; sebagai topeng untuk menyembunyikan wajah asli dari suatu kejahatan.

Kejahatan korporasi sebagai organized crime diakui sebagai kejahatan yang terorganisir dan aktivitasnya memberikan ancaman nyata terhadap stabilitas global. Sebagai kejahatan yang terorganisir, kejahatan korporasi merupakan kejahatan dari orang-orang yang secara bersamasama mengikatkan diri karena adanya kesamaan pandangan yang berlaku secara hirarki untuk mencapai suatu tujuan dengan cara melawan hukum (Harkrisnowo, 2004).

Ancaman nyata kejahatan korporasi sebagai perusak perekonomian bahkan mengancam nyawa manusia semakin terlihat dalam cerminan kasus-kasus korporasi yang marak terjadi pada saat terjadinya pandemi Covid-19 sejak akhir tahun 2019. Banyaknya permasalahan tersebut nampak dari tindakan-tindakan tidak sah aparat pemerintah yang memotong nominal bantuan sosial kepada masyarakat dengan alasan yang tidak dapat dibenarkan (Kompas, 2021), kemudian adanya kasus suap-gratifikasi untuk pengaturan pemenang tender/proyek pengadaan sembako bansos di lingkungan Dinas Sosial (Dinsos) Bandung Barat Tahun 2020 yang melibatkan Bendahara Dinsos Bandung Barat PN dengan CV. JCM, CV. SJ, PT. JDG, dan CV. SSGCL dengan total nilai suap sebesar 2,7 Milyar Rupiah (Liputan 6, 2021), hingga korupsi Pengadaan Barang/Jasa Bantuan Sosial Sembako Dalam Rangka Penanganan Corona Virus Disease 2019 (Covid-19) yang terjadi dalam kurun waktu Mei 2020 sampai dengan Oktober 2020 dengan 
melibatkan beberapa korporasi seperti PT. RPI dan PT. MHS (Putusan Nomor: 8/Pid.SusTpk/2021/PN.Jkt.Pst, 2021). Kasus korupsi yang melibatkan korporasi dan pejabat pemerintah menjadi perhatian serius dikala Indonesia sedang menghadapi pandemi Covid-19 yang telah ditetapkan oleh pemerintah sebagai Bencana Non-Alam (Keppres No 12 Tahun 2020 Tentang Penetapan Bencana Nonalam Penyebaran Corona Virus Disease 2019 Sebagai Bencana Nasional, 2020).

Perbuatan tersebut tentu membawa konsekuensi dapat dikenakannya sanksi pidana terhadap korporasi. Penjatuhan sanksi pidana terhadap korporasi sangat berkaitan erat dengan asas pertanggungjawaban pidana korporasi (Setiyono, 2005). Persoalan mengenai pertanggungjawaban pidana (Legowo \& Wahyuningsih, 2017) pada korporasi akan selalu berpedoman pada kemampuan korporasi dinyatakan sebagai pelaku atau terbukti melakukan tindak pidana untuk kepentingan korporasi, kriteria untuk mempertanggungjawabkan perbuatan korporasi tersebut, serta pidana apa yang tepat untuk dikenakan kepada korporasi.

Berdasarkan pemaparan tersebut, rumusan masalah yang dapat ditarik dalam pembahasan adalah penindakan kejahatan korporasi terutama dalam tindak pidana korupsi yang dilakukan di masa pandemi dan adanya ketimpangan aturan hukum atas status pandemi Covid-19 dengan peraturan perundang-undangan di bidang korupsi yang dimanfaatkan oleh korporasi untuk melakukan kejahatan. Penulisan ini bertujuan untuk memberikan gambaran utuh keterkaitan penindakan atas kejahatan korporasi dengan UU Pemberantasan TPK dan situasi pandemi Covid-19 sebagai Bencana Non-Alam.

\section{Metode Penelitian}

Penelitian hukum merupakan suatu kegiatan ilmiah yang didasarkan pada metode, sistematika dan pemikiran tertentu, yang bertujuan untuk mempelajari satu atau beberapa gejala hukum tertentu dengan jalan menganalisanya (Suryoputro et al., 2012). Penelitian ini bersifat deskriptif secara yuridis normatif, menggunakan data sekunder, bahan hukum primer dan sekunder. Penyelesaian masalah dalam penelitian ini menggunakan pendekatan peraturan perundang-undangan (statute approach), pendekatan kasus (case approach), dan pendekatan konseptual (conseptual approach) dengan teknik pengumpulan data secara kepustakaan dan dianalisis secara kualitatif.

\section{Hasil Penelitian dan Pembahasan}

\subsection{Tipologi Kejahatan Korporasi dalam Korupsi di Masa Pandemi}

Perkembangan kehidupan manusia dan perekonomian masyarakat global yang semakin kompleks (Puspitasari \& Devintawati, 2018) sangat dipengaruhi oleh berbagai aspek, salah satunya termasuk situasi pandemi Covid-19 yang secara resmi telah ditetapkan oleh WHO pada tanggal 11 Maret 2020 sebagai Global Pandemic (World Health Organization, 2020). Ancaman nyata penularan dan penyebaran penyakit Covid-19 dihadapi oleh hampir setiap negara, termasuk Indonesia (Suardana et al., 2020). Berdasarkan data dari Komite Penanganan Covid-19 dan Pemulihan Ekonomi Nasional, Indonesia mengkonfirmasi adanya 1.775.220 kasus Covid-19 dengan jumlah kematian sebesar 49.328 jiwa (Nasional, 2021). Angka-angka tersebut dapat terus bertambah seiring masih berlanjutnya pandemi Covid-19 di Indonesia. 
Jurnal Yustika

Vol.24 No. 01, Jul 2021

Halaman I 5

Tipologi

Penindakan

Kejahatan

Korporasi Dalam

Korupsi Dana

Bantuan Pandemi Covid-19

Michelle Kristina
Situasi demikian menuntut pemerintah Indonesia untuk bergerak cepat dalam mengatasi permasalahan pandemi Covid-19. Salah satu kebijakan pemerintah dengan menerbitkan aturan terkait Pembatasan Sosial Berskala Besar (PSBB) (Peraturan Pemerintah Nomor 21 Tahun 2020 tentang Pembatasan Sosial Berskala Besar Dalam Rangka Percepatan Penanganan Corona Virus Disease 2019 (COVID-19), 2020). Kebijakan penerapan PSBB tersebut mengharuskan masyarakat yang terdampak wabah penyakit Covid-19 untuk melakukan pembatasan kegiatan. Pembatasan tersebut meliputi pembatasan proses kerja di tempat kerja (work from home), pembatasan proses belajar-mengajar, pembatasan kegiatan keagamaan di rumah ibadah, pembatasan kegiatan di tempat umum, pembatasan kegiatan sosial dan budaya, serta pembatasan penggunaan moda transportasi.

Pembatasan-pembatasan tersebut mengakibatkan situasi perekonomian di Indonesia mengalami penurunan sebesar 2,07\% pada tahun 2020 jika dibandingkan dengan tahun 2019 (Badan Pusat Statistik, 2021). Menanggapi situasi penurunan daya beli masyarakat dalam situasi pembatasan tersebut, pemerintah melalui Kementerian Sosial kemudian pada bulan April tahun 2020 mengadakan program Pengadaan Barang/Jasa Bantuan Sosial Sembako Dalam Rangka Penanganan Corona Virus Disease 2019 (Covid-19) pada Direktorat Perlindungan Sosial Korban Bencana Sosial Kementerian Sosial Tahun 2020 yang akan disalurkan untuk masyarakat pada bulan April-Desember 2020.

Pengadaan Bantuan Sosial tersebut kemudian melibatkan beberapa korporasi, salah satunya adalah PT. MHS sebagai penyedia paket bantuan sosial dengan nilai proyek sebesar Rp6.840.000.000.000,00 (enam triliun delapan ratus empat puluh miliar rupiah) dari Kementerian Sosial. PT. MHS dalam proses pelaksanaan program paket bantuan sosial Covid-19 tersebut, melalui HVS memberi uang sebesar Rp1.280.000.000,00 (satu miliar dua ratus delapan puluh juta rupiah) kepada JPB selaku Menteri Sosial. Jumlah uang tersebut merupakan fee yang sudah disepakati atas setiap paket bantuan sosial yang didapatkan dan dikerjakan oleh PT. MHS. Pada proses di persidangan, HVS kemudian terbukti secara sah melakukan tindak pidana korupsi, melanggar Pasal 5 ayat (1) UU Pemberantasan TPK.

Pun demikian, masih pada tahun 2020, terjadi kasus korupsi dengan modus operandi yang sama berupa adanya suap-gratifikasi sebesar 2,7 Milyar Rupiah yang melibatkan Bendahara Dinsos Bandung Barat PN dengan beberapa korporasi seperti CV. JCM, CV. SJ, PT. JDG, dan CV. SSGCL. Pada kasus pengadaan bantuan sosial oleh Dinsos Bandung Barat tersebut, korporasikorporasi tersebut setuju untuk memberikan suap-gratifikasi dengan nominal sesuai dengan persenan atas nilai setiap paket bantuan sosial yang diadakan dalam proyek tersebut sehingga korporasi-korporasi tersebut berhasil memenangkan proses pengadaan proyek bantuan sosial tersebut.

Berdasarkan pemarapan kasus-kasus tersebut, terdapat karakteristik yang hampir sama yaitu kedudukan perkara korupsi bantuan sosial Covid-19 melibatkan korporasi sebagai pelaksana program. Jika dicermati, UU Pemberantasan TPK mengakomodasi dapat dijeratnya korporasi sebagai pelaku dalam tindak pidana korupsi. Hal tersebut tertuang dalam Pasal 1 angka 3 UU Pemberantasan TPK yang menyatakan bahwa subyek hukum dalam UU tersebut adalah orang perorangan dan korporasi. Lebih lanjut, pasal-pasal yang terkandung telah mengkualifikasikan perbuatan-perbuatan dalam UU Pemberantasan TPK sedemikian rupa sehingga korporasi juga dapat dijerat.

Hal tersebut dapat dilihat dalam Pasal 2 dan Pasal 3 UU Pemberantasan TPK yang mengatur tentang kerugian keuangan negara dan Pasal 5 ayat (1), Pasal 6 ayat (1), dan Pasal 13 
UU Pemberantasan TPK yang mengatur tentang suap-menyuap (Komisi Pemberantasan Korupsi, 2006). Perumusan perbuatan-perbuatan tersebut dikualifikasi dapat dilakukan oleh setiap orang, artinya baik orang perorangan maupun korporasi. Pengaturan mengenai perbuatan-perbuatan yang dapat korporasi lakukan dalam UU tersebut membawa konsekuensi dapat dikenakannya sanksi pidana terhadap korporasi apabila terbukti melakukan tindak pidana dalam pasal-pasal tersebut.

Tindak pidana atau straafbaarfeit (Utrecht, 1987) merupakan peristiwa atau perbuatan pidana yang memiliki akibat yang timbul karena perbuatan yang melalaikan atau melanggar ketentuan yang telah diatur oleh hukum. Berkaca pada perbuatan yang dilakukan oleh HVS yang telah melanggar Pasal 5 ayat (1) UU Pemberantasan TPK, maka perlu dikaji perbuatan pidana yang dilakukan oleh PT. MHS. Dikaitkan dengan Pasal 4 ayat (2) Perma No. 13 Tahun 2016 (Peraturan Mahkamah Agung, 2016) bahwa faktor untuk dapat menjatuhkan pidana kepada korporasi yaitu adanya keuntungan atau manfaat yang korporasi terima atas perbuatan pidana tersebut atau tindak pidana tersebut dilakukan untuk kepentingan korporasi (crimes for corporation).

Berpedoman pada Perma No. 13 Tahun 2016, perbuatan korupsi atas satuan nilai paket bantuan sosial Covid-19 memberikan aliran keuntungan kepada PT. MHS selaku korporasi pelaksana program. Keuntungan tersebut terbukti dari keberhasilan PT. MHS ditunjuk sebagai korporasi pelaksana program setelah HVS sepakat memberikan fee kepada JPB sesuai dengan banyaknya jumlah pengadaan paket yang PT. MHS terima. Terlebih berdasarkan perbuatan tersebut, PT. MHS juga telah melanggar Pasal 4 ayat (2) huruf b dan c Perma No. 13 tahun 2016, yaitu korporasi tidak melakukan langkah pencegahan untuk memastikan korporasi patuh terhadap aturan hukum.

Permasalahan kemudian muncul pada saat perbuatan pidana tersebut dilakukan dalam situasi pandemi. Telah dijelaskan bahwa tindak pidana korupsi tersebut dilakukan terhadap Pengadaan Barang/Jasa yang diperuntukan bagi masyarakat yang terdampak pandemi Covid19. Berdasarkan Keppres No. 12 tahun 2020, Covid-19 telah ditetapkan sebagai Bencana Nasional berupa Bencana Non-Alam. UU Penanggulangan Bencana mengatur 3 jenis Bencana Nasional, yaitu Bencana Alam, Bencana Nonalam, dan Bencana Sosial (Undang-Undang Nomor 24 Tahun 2007 tentang Penanggulangan Bencana, 2007).

Adanya perbedaan situasi berimplikasi pula pada perbedaan terhadap sanksi yang dapat dijatuhkan. Hal tersebut tercermin dalam Pasal 2 ayat (2) UU Pemberantasan TPK. Dinyatakan bahwa tindak pidana korupsi yang dilakukan dalam keadaan tertentu dapat dijatuhkan pidana mati. Ketentuan pasal tersebut memang hanya ditujukan atas tindak pidana Pasal 2 ayat (1) UU Pemberantasan TPK. Pidana mati tersebut juga hanya dapat diberikan kepada orang perorangan. Korporasi sebagai pelaku tindak pidana hanya dapat diberikan sanksi pidana pokok berupa pidana denda (Pasal 20 ayat (7) UU Pemberantasan TPK). Namun keberadaan Pasal 2 ayat (2) tersebut menunjukan bahwa sejatinya UU Pemberantasan TPK memberikan perbedaan atau pemberatan sanksi terhadap tindak pidana yang dilakukan dalam situasi-situasi tertentu.

Terlebih penjelasan Pasal 2 UU Pemberantasan TPK menegaskan bahwasannya yang dimaksud keadaan tertentu sebagai alasan pemberatan pidana pada pelaku tindak pidana korupsi yaitu tindak pidana korupsi yang dilakukan terhadap dana-dana yang diperuntukan bagi bencana alam nasional. Namun penjelasan pasal tersebut justru semakin mempersempit ruang lingkup UU Pemberantasan TPK dalam menjangkau perbuatan-perbuatan korupsi yang dilakukan dalam masa pandemi Covid-19 yang dikategorikan sebagai Bencana Nonalam. 
Jurnal Yustika

Vol.24 No. 01, Jul 2021

Halaman | 7

Tipologi

Penindakan

Kejahatan

Korporasi Dalam

Korupsi Dana Bantuan Pandemi Covid-19

Michelle Kristina
Mengacu pada UU Penanggulangan Bencana, dinyatakan bahwa Bencana Alam, Bencana Nonalam, maupun Bencana Sosial merupakan bagian dari Bencana sebagai peristiwa yang mengancam dan mengganggu kehidupan masyarakat dan berdampak pada lingkungan, harta benda, dan psikologis. Dengan demikian, penjelasan pasal UU Pemberantasan TPK seharusnya tidak semakin mempersempit ruang lingkup tindak pidana korupsi pada bencana-bencana tertentu saja. Hal tersebut disebabkan UU Penanggulangan Bencana menempatkan ketiga macam jenis yaitu Bencana Alam, Bencana Nonalam, dan Bencana Sosial sebagai Bencana.

Berdasarkan pengaturan tersebut, ketiga jenis bencana tersebut memiliki implikasi yang sama terhadap dana-dana yang diperuntukan bagi penanganan bencana sebagai situasi khusus yang layak mendapat perhatian lebih dari proses penegakan hukum. Sehingga proses penindakan terhadap tindak pidana korupsi atas penggunaan dana-dana bencana seharusnya dapat diakomodasi secara utuh oleh UU Pemberantasan TPK. Gambaran atas ketimpangan pengaturan dalam kedua UU tersebut semakin menegaskan betapa sempitnya jangkauan UU Pemberantasan TPK terhadap tindak pidana korupsi yang dilakukan dalam situasi pandemi Covid-19. Terlebih terhadap korporasi sebagai pelaku tindak pidana korupsi.

\subsection{Sanksi Kejahatan Korporasi dalam Korupsi di Masa Pandemi}

Korporasi sebagai subyek hukum pidana membawa konsekuensi dapat dikenakannya sanksi pidana terhadap korporasi. Terhadap hal ini pertama, perlu dirumuskan secara tegas adanya suatu tindak pidana yang dilakukan oleh atau atas nama korporasi (Setiyono, 2005). Kedua, pertanggungjawaban pidana korporasi tidak dapat dilepaskan dan selalu dikaitkan dengan masalah kemampuan bertanggung jawab yang dikaitkan dengan doktrin ultra vires atau pembatasan pertanggungjawaban korporasi (Kinanti et al., 2016). Ketiga, sanksi yang diberikan kepada korporasi harus tepat (Yatini, 2019).

Perumusan tindak pidana tersebut dapat dilihat pengaturannya pada Pasal 2, 3, 5 ayat (1), 6 ayat (1), dan Pasal 13 UU Pemberantasan TPK. Dinyatakan bahwa korporasi dapat melakukan tindak pidana korupsi sebagaimana pasal-pasal tersebut mengatur, berupa kerugian keuangan negara dan melakukan suap-menyuap. Tujuan dilakukannya perbuatan tersebut oleh korporasi agar korporasi memperoleh keuntungan berupa memperkaya diri sendiri atau mendorong pejabat negara untuk berbuat atau tidak berbuat sesuatu dalam fungsi jabatannya.

Unsur yang kedua mengenai pertanggungjawaban pidana korporasi merupakan pertanggungjawaban korporasi terhadap tindak pidana yang dilakukannya (Huda, 2006). Penerapan pertanggungjawaban pidana pada korporasi sangat terbatas sejauh mana tindakan yang korporasi tersebut lakukan. Adanya maksud dan tujuan dari pembatasan ini sangat diperlukan karena hukum dijatuhkan setimpal dengan perbuatannya (culpue poena par esto). Batasan pertanggungjawaban pidana korporasi dikenal dengan ajaran atau doctrine of ultra vires (Sjahdeini, 2007). Pembatasan tersebut dilakukan karena korporasi tidak bertanggung jawab apabila kegiatan yang dilakukan tidak sesuai atau menyimpang dengan tujuan dari korporasi tersebut (Hertanto, 2007).

Doktrin ajaran ultra vires yang membatasi pertanggungjawaban pidana korporasi dapat dilihat semakin jelas dengan adanya kriteria kesalahan korporasi dalam pertanggungjawaban korporasi. Hal ini dapat dilihat dalam Perma No. 13 Tahun 2016 yang menentukan bahwa hakim dapat menilai diantaranya tiga kesalahan korporasi sehingga dapat dimintakan pertanggungjawaban pidana. 
Tiga kesalahan tersebut adalah korporasi dapat memperoleh keuntungan atau manfaat dari tindak pidana atau tindak pidana dilakukan untuk kepentingan korporasi; korporasi membiarkan terjadinya tindak pidana; atau korporasi tidak melakukan langkah-langkah pencegahan. Dengan demikian, pembatasan pertanggungjawaban pidana serta adanya kriteria kesalahan korporasi semakin memperjelas sampai sejauh mana korporasi dapat dimintakan pertanggungjawaban pidana. Kehadiran Perma No. 13 Tahun 2016 semakin melengkapi aturan Pasal 20 ayat (2) UU Pemberantasan TPK, yaitu tindak pidana korupsi dianggap dilakukan oleh korporasi apabila dilakukan oleh orang-orang dalam lingkungan korporasi tersebut.

Terkait dengan pertanggungjawaban pidana korporasi, ada 3 (tiga) sistem yang dapat digunakan agar korporasi dapat dimintakan pertanggungjawaban pidana, yaitu pengurus korporasi sebagai pembuat, penguruslah yang bertanggungjawab; korporasi sebagai pembuat, pengurus yang bertanggungjawab; dan korporasi sebagai pembuat dan yang bertanggungjawab (Amrani \& Ali, 2015).

Pertanggungjawaban pidana kepada korporasi yang melakukan tindak pidana sangat diperlukan dengan adanya alasan bahwa korporasi dalam melakukan tindak pidana sering berkaitan dengan ekonomi dan fiskal, sehingga keuntungan yang diperoleh korporasi ataupun kerugian yang diderita masyarakat sangat besar. Keberadaan korporasi demikian dapat terjadi karena adanya karakteristik dari kejahatan korporasi sebagai white collar crime dan semakin beragamnya pula jenis kejahatan yang ada. Selain itu diperlukan juga adanya pemberian efek jera bagi korporasi agar tidak mengulangi melakukan perbuatan pidana dan dapat menaati peraturan yang bersangkutan (Setiyono, 2005).

Telah disebutkan bahwa sanksi pidana pokok yang dapat dijatuhkan kepada korporasi hanya berupa pidana denda. Pengaturan tersebut merupakan jawaban atas persoalan sanksi yang diberikan kepada korporasi harus tepat. Berdasarkan Pasal $10 \mathrm{KUHP}$, jenis-jenis pidana pokok yang dapat diterapkan kepada korporasi hanyalah pidana denda saja. Hal tersebut semakin dipertegas dalam Pasal 20 ayat (7) UU Pemberantasan TPK.

Namun, berkaca pada situasi tindak pidana korupsi yang dilakukan oleh korporasi pada masa pandemi, maka layak apabila sanksi terhadap korporasi dikualifikasikan sebagai cara untuk menjerakan korporasi sekaligus mengembalikan nilai keadilan bagi masyarakat. Cara tersebut dapat dilakukan melalui pidana pokok, pidana tambahan, serta sanksi berupa tindakan. Selain itu, dalam situasi khusus seperti pandemi Covid-19 tersebut maka layak pula jika pelaku tindak pidana, dalam hal ini adalah korporasi, juga dijatuhkan pemberatan pidana sebagai langkah pemberian efek jera (detterent effect) sehingga tercipta keadilan. Hal tersebut karena dampak yang ditimbulkan dari adanya kejahatan korporasi sangatlah besar bagi korban (Widowaty, 2012), dalam hal ini adalah masyarakat yang sedang berjuang melawan pandemi dan sangat membutuhkan bantuan sosial.

Ketentuan Pasal 20 ayat (7) UU Pemberantasan TPK mengatur adanya pidana denda dengan maksimum pidana ditambah $1 / 3$ (sepertiga). Pun Pasal 18 ayat (1) huruf c UU Pemberantasan TPK mengatur bahwa selain pidana tambahan yang telah diatur dalam KUHP, korporasi dapat diberikan pidana tambahan berupa penutupan seluruh atau sebagai korporasi maksimal 1 tahun lamanya. Lebih lanjut, Pasal 20 Perma No. 13 Tahun 2016 menyatakan bahwa korban yang mengalami kerugian akibat tindakan korporasi dapat meminta ganti rugi.

Telah dinyatakan pula bahwa tindak pidana tersebut dilakukan dalam suatu situasi khusus sehingga sejatinya UU Pemberantasan TPK perlu mengkualifikasikan sanksi pidana yang dijatuhkan sebagai langkah-langkah untuk menjerakan sekaligus dalam upaya menciptakan 
Jurnal Yustika

Vol.24 No. 01, Jul 2021

Halaman I 9

Tipologi

Penindakan

Kejahatan

Korporasi Dalam

Korupsi Dana Bantuan Pandemi Covid-19

Michelle Kristina perlindungan pada masyarakat saat situasi mendesak karena bencana (Arief, 1996). Korporasi hadir sebagai bagian dari sistem pemenuhan kebutuhan hidup manusia yang semakin beragam dan kompleks dewasa ini. Namun, sebagai sebuah subjek hukum yang berorientasi pada keuntungan, maka tidak dapat dipungkiri bila korporasi melakukan kejahatan. Setidaknya terdapat tiga variabel yang mempengaruhi korporasi melakukan kejahatan, yaitu:

a. profit oriented dengan anomie of success;

b. kontradiksi kebutuhan sehingga melanggar aturan hukum;

c. sistem penegakan hukum yang tidak efektif (Suhartati et al., 2018).

Menyadari adanya berbagai sebab tersebut, kebijakan hukum pidana perlu mengedepankan sistem pencegahan sekaligus penegakan hukum demi melindungi masyarakat. Sistem pencegahan terhadap kejahatan korporasi dapat dilakukan dengan adanya pengawasan dari negara. Bentuk pengawasan ini dapat diejawantahkan dalam kebijakan hukum pidana sehingga korporasi mendapatkan perhatian secara nyata dalam menjalankan bisnis usahanya sehingga tidak melakukan kejahatan korporasi.

Berkaitan dengan dasar pemikiran tersebut, korporasi yang melakukan tindak pidana korupsi atas dana-dana yang diperuntukan bagi penanganan Covid-19 sebagai Bencana Nonalam perlu dibebankan sanksi pidana yang tidak didasarkan pada sanksi pidana pada situasi normal. Hal tersebut telah dinyatakan bahwa dana-dana tersebut diperuntukan untuk mengatasi keadaan tertentu yang seharusnya menjadi ruang lingkup UU Pemberantasan TPK. Hukum pidana sejatinya harus melindungi masyarakat dalam situasi mendesak seperti pandemi Covid19 ini. Dengan demikian, sanksi yang dijatuhkan kepada korporasi tidak dapat hanya terbatas pada pengaturan-pengaturan hukum dalam situasi normal saja. Melainkan perlu adanya pemberatan sanksi pidana sebagai cara untuk menjerakan korporasi. Terutama agar kejadian tindak pidan korupsi dengan memanfaatkan situasi atau keadaan tertentu tidak lagi terjadi.

Tidak dapat dinafikan dalam mengatasi kejahatan korporasi perlu adanya penegakan hukum untuk memberantas terjadinya suatu tindak pidana oleh korporasi. Hingga saat ini, telah ada puluhan peraturan perundang-undangan yang mengakui korporasi sebagai subjek hukum (Yatini, 2019). Efektifitas penegakan hukum juga berkaitan dengan adanya pemidanaan kepada korporasi. Pada dasarnya terdapat tiga pokok pemikiran tentang tujuan yang ingin dicapai dengan suatu pemidanaan, yaitu:

1. untuk memperbaiki diri;

2. untuk membuat jera dalam melakukan kejahatan;

3. untuk membuat tidak mampu melakukan kejahatan yang lain. (Lamintang \& Lamintang, 2010)

Berdasarkan pendapat tersebut, perlu adanya pemidanaan kepada korporasi sehingga korporasi dapat memperbaiki diri, mendapatkan efek jera, dan korporasi tersebut tidak melakukan kejahatan yang lain.

Terlebih pada situasi pandemi, kehadiran pokok pemikiran yang mengedepankan tujuan dari adanya pemidanaan terhadap kejahatan korporasi sangat berkaitan dengan upaya memberikan penjeraan baik secara umum maupun khusus atas tindakan korporasi. Kejahatan korporasi dalam korupsi dana bantuan sosial pandemi Covid-19 tersebut tidak hanya melanggar undang-undang saja melainkan juga melanggar:

a. Pelanggaran norma hukum yang berlaku di masyarakat;

b. Penyalahgunaan kepercayaan (trust) yang diberikan oleh negara dan masyarakat kepada korporasi (Suhartati et al., 2018).

Selain itu, dengan adanya pemberian berbagai macam jenis sanksi baik berupa pidana pokok maupun tindakan serta adanya pemberatan pidana maka hukum berperan untuk mengembalikan nilai-nilai keadilan bagi masyarakat, terkhusus bagi korban.

UU Pemberantasan TPK dan Perma No. 13 Tahun 2016 menentukan bahwa penjatuhan pidana terhadap korporasi berupa pidana pokok dan/atau pidana tambahan. Dalam hal ini, pidana pokok yang dimaksud berupa pidana denda sebagaimana telah dijelaskan. Dengan 
demikian pidana denda seharusnya dapat dirasakan penderitaannya (efek jera) kepada mereka yang dijatuhinya, namun tidak didasarkan pada pemikiran besar atau kecilnya denda yang dijatuhi, melainkan pada keseimbangan antara pidana denda dengan perbuatan serta akibat yang ditimbulkan (Suparni, 2007). Sulitnya menentukan pidana yang dapat dikenakan terhadap korporasi berkaitan dengan jenis-jenis pidana tertentu saja yang dapat dikenakan terhadap korporasi (Alhakim \& Soponyono, 2019). Terhadap korporasi dapat dijatuhkan pidana denda. Namun, penjatuhan pidana terhadap korporasi yang melakukan tindak pidana harus memperhatikan keseimbangan terhadap sanksi pidana yang dapat diterapkan kepada korporasi itu sendiri maupun terhadap individu dari korporasi tersebut.

Berdasarkan pembahasan tersebut, pertanggung jawaban yang dapat dimintakan terhadap korporasi dapat dilaksanakan secara proporsional tanpa mengorbankan yang lain. Namun UU Pemberantasan TPK perlu dilakukan beberapa penyesuaian mengingat perkembangan kejahatan korporasi yang semakin luas. Terutama dalam menjangkau situasisituasi khusus atau keadaan tertentu yang dapat dimanfaatkan untuk melakukan tindak pidana korupsi. Bahwasannya sanksi pidana dalam bentuk pemberatan telah menjadi buah pikir yang terkandung dalam Pasal 2 ayat (2) UU Pemberantasan TPK. Namun pandangan tersebut tidak dielaborasikan lebih lanjut dalam kualifikasi perbuatan-perbuatan pidana yang dilakukan oleh korporasi sehingga hal ini menimbulkan ketimpangan antara pidana pokok terhadap korporasi.

Berkaca pada permasalahan demikian, penegak hukum dapat memaksimalkan upaya penjeraan korporasi menggunakan pidana tambahan berupa penutupan sebagian atau seluruh korporasi. Akan tetapi, hal tersebut juga mengalami keterbatasan karena tidak adanya perbedaan terhadap situasi pandemi yang masyarakat hadapi. Dengan demikian, perlu adanya terobosan hukum pidana baru dalam ruang lingkup kejahatan korporasi sehingga hukum pidana mampu menjalankan fungsinya sebagai pelindung masyarakat. Terlebih dalam situasi-kondisi masyarakat Indonesia yang sedang menghadapi kedaruratan kesehatan. Sehingga segala bentuk kejahatan korporasi yang terjadi dengan memanfaatkan situasi tersebut demi mendapatkan keuntungan yang tidak sah layak untuk diberikan pemberatan pidana sebagaimana telah diatur oleh peraturan perundang-undangan.

\section{Kesimpulan}

Dimensi kriminal kejahatan korporasi di Indonesia terus berkembang seiring dengan perkembangan perekonomian nasional dan internasional. Kejahatan korporasi sebagai organized crime diakui sebagai kejahatan yang terorganisir dan aktivitasnya memberikan ancaman nyata terhadap stabilitas global. Hal tersebut yang menyebabkan perlu adanya pengaturan mengenai Kejahatan Korporasi (corporate crime). Pengaturan mengenai korporasi dalam UU Pemberantasan TPK menunjukan bahwa korporasi dapat melakukan kejahatan korporasi. Ancaman nyata kejahatan korporasi sebagai perusak perekonomian bahkan mengancam nyawa manusia semakin terlihat dalam cerminan kasus korupsi Pengadaan Barang/Jasa Bantuan Sosial Sembako Dalam Rangka Penanganan Corona Virus Disease 2019 (Covid-19). Pengadaan Bantuan Sosial baik di lingkungan Kementerian Sosial maupun di Dinsos Bandung Barat tersebut kemudian menjerat berbagai korporasi yang hendak memanfaatkan situasi pandemi demi keuntungan yang tidak sah diantaranya CV. JCM, CV. SJ, PT. JDG, CV. SSGCL, PT. RPI, dan PT. MHS sebagai korporasi penyedia paket bantuan sosial. UU Pemberantasan TPK mengakomodasi dapat dijeratnya korporasi sebagai pelaku dalam tindak pidana korupsi. Sejatinya Pasal 2 ayat (2) UU
Jurnal Yustika Vol.24 No. 01, Jul 2021

Halaman | 10 Tipologi Penindakan Kejahatan Korporasi Dalam Korupsi Dana Bantuan Pandemi Covid-19

Michelle Kristina 
Jurnal Yustika

Vol.24 No. 01, Jul 2021

Halaman | 11

Tipologi

Penindakan

Kejahatan

Korporasi Dalam

Korupsi Dana

Bantuan Pandemi Covid-19

Michelle Kristina
Pemberantasan TPK menunjukan bahwa UU memberikan perbedaan atau pemberatan sanksi terhadap tindak pidana yang dilakukan dalam situasi-situasi tertentu. Penindakan terhadap tindak pidana korupsi atas penggunaan dana-dana bencana seharusnya dapat diakomodasi secara utuh oleh UU Pemberantasan TPK. Terdapat ketimpangan pengaturan dalam UU Pemberantasan TPK terhadap tindak pidana korupsi yang dilakukan dalam situasi pandemi Covid-19. Terlebih terhadap korporasi sebagai pelaku tindak pidana.

Pertanggungjawaban pidana kepada korporasi yang melakukan tindak pidana sangat diperlukan. Perlu adanya pemidanaan kepada korporasi sehingga korporasi dapat memperbaiki diri, mendapatkan efek jera, dan korporasi tersebut tidak melakukan kejahatan yang lain. Sanksi pidana yang dapat dijatuhkan kepada korporasi harus tepat yaitu pidana denda dan pidana tambahan serta tindakan dan ganti kerugian kepada korban sebagai bentuk keadilan. Penjatuhan pidana terhadap korporasi berupa pidana denda seharusnya dapat dirasakan penderitaannya (efek jera) sebagai keseimbangan antara pidana perbuatan serta akibat yang korporasi timbulkan. Pertanggung jawaban yang dapat dimintakan terhadap korporasi dapat dilaksanakan secara proporsional. UU Pemberantasan TPK perlu dilakukan beberapa penyesuaian mengingat perkembangan kejahatan korporasi yang semakin luas. Terutama dalam menjangkau situasisituasi khusus atau keadaan tertentu sehingga perlu pengaturan sanksi pidana terhadap korporasi dalam kualifikasi pemberatan pidana atas keadaan tertentu dan memaksimalkan upaya penjeraan korporasi menggunakan pidana tambahan serta ganti rugi untuk memulihkan masyarakat yang menjadi korban. Oleh sebab itu, sangatlah layak kejahatan korporasi dalam tindak pidana korupsi dana bantuan sosial Covid-19 tersebut untuk dijatuhkan pemberatan sanksi pidana selain jenis sanksi lainnya juga.

\section{Daftar Referensi}

Buku:

Ali, M. (2008). Kejahatan Korporasi. Arti Bumi Intaran.

Ali, M. (2013). Asas-Asas Hukum Pidana Korporasi (Cet. I). Raja Grafindo Persada.

Amrani, H., \& Ali, M. (2015). Sistem Pertanggungjawaban Pidana: Perkembangan dan Penerapan (Cet.I). Rajawali Pers.

Arief, B. N. (1996). Bunga Rampai Kebijakan Hukum Pidana. Citra Aditya Bakti.

Budianto, A. (2013). Corporate Crime As The Power of Crime.

Harkrisnowo, H. (2004). Transnational Organized Crime: Dalam Perspektif Hukum Pidana dan Kriminologi.

Hatrik, H. (1996). Asas Pertanggungjawaban Korporasi Dalam Hukum Pidana Indonesia. Raja Grafindo Persada.

Huda, C. (2006). Dari Tiada Pidana Tanpa Kesalahan Menuju Kepada Tiada Pertanggungjawaban Pidana Tanpa Kesalahan. Kencana Prenada Media.

Komisi Pemberantasan Korupsi. (2006). Memahami Untuk Membasmi: Buku Saku Untuk Memahami Tindak Pidana Korupsi. Komisi Pemberantasan Korupsi.

Lamintang, P. A. F., \& Lamintang, T. (2010). Hukum Penitensier Indonesia (Ed. II). Sinar Grafika.

Sahetapy, J. E. (1994). Kejahatan Korporasi. ERESCO.

Setiyono. (2005). Kejahatan Korporasi. Bayumedia Publishing.

Sjahdeini, S. R. (2007). Pertanggungjawaban Pidana Korporasi. Grafiti Pers.

Suhartati, Sahetapy, E. L., \& Christianto, H. (2018). Buku Ajar ANATOMI KEJAHATAN 
KORPORASI.

Suparni, N. (2007). Eksistensi Pidana Denda dalam Sistem Pidana dan Pemidanaan. Sinar Grafika.

Suryoputro, G., Riadi, S., \& Syaban, A. (2012). Menulis Artikel untuk Jurnal Umum.

Utrecht, E. (1987). Ringkasan Sari Kuliah Hukum Pidana II. Pustaka Tinta Mas.

Yunara, E. (2005). Korupsi dan Pertanggungjawaban Pidana Korporasi: Berikut Studi Kasus. Citra Aditya Bakti.

Artikel Jurnal:

Alhakim, A., \& Soponyono, E. (2019). Kebijakan Pertanggungjawaban Pidana Korporasi Terhadap Pemberantasan Tindak Pidana Korupsi. Jurnal Pembangunan Hukum Indonesia, 1(3), 322-336.

Burhanudin. (2013). Tindak Pidana Korupsi Sebagai Kejahatan Korporasi. Journal Cita Hukum, 53(9), 1689-1699. https:/ / doi.org/10.1017/CBO9781107415324.004

Hertanto, A. W. (2007). PELUANG PEMULIHAN T1NDAKAN ULTRA VIRES D1REKSI SUATU PERSEROAN TERBATAS. Jurnal Hukum \& Pembangunan, 37(1), 22. https://doi.org/10.21143/jhp.vol37.no1.147

Hikmawati, P. (2017). Kendala Penerapan Pertanggungjawaban Pidana Korporasi Sebagai Pelaku Tindak Pidana Korupsi. Negara Hukum, 8(1), 131-150.

Kinanti, A., Saptono, H., \& Mahmudah, S. (2016). Tanggung Jawab Direksi Dalam Tindakan Ultra Vires Menurut UU Nomor 40 Tahun 2007 Tentang Perseroan Terbatas. 5(40), 1-13.

Legowo, B. P. D. A., \& Wahyuningsih, S. E. (2017). Kebijakan Hukum Pidana Pertanggungjawaban Korporasi Terhadap Tindak Pidana Perbankan Dalam Sistem Hukum di Indonesia. Jurnal Hukum Khaira Ummah, 12(3), 527-546.

Prasetyo, R. T., Ma'ruf, U., \& Mashdurohatun, A. (2017). Tindak Pidana Korporasi Dalam Perspektif Kebijakan Formulasi Hukum Pidana. Jurnal Hukum Khaira Ummah, 12(4), 9931002.

Puspitasari, I., \& Devintawati, E. (2018). Urgensi Pengaturan Kejahatan Korporasi dalam Pertanggungjawaban Tindak Pidana Korporasi Menurut RKUHP. Kanun: Jurnal Ilmu Hukum, 20(2), 237-254. https://doi.org/10.24815/kanun.v20i2.10661

Satria, H. (2018). Pembuktian Kesalahan Korporasi dalam Tindak Pidana Korupsi. Jurnal Integritas, 4(02), 25-53.

Suardana, I. W., Wairocana, I. G. N., \& Jaya, I. B. S. D. (2020). Pembatasan Sosial Berskala Besar (PSBB). Jurnal Kertha Semaya, 8(9), 27.

Widowaty, Y. (2012). PERTANGGUNGJAWABAN PIDANA KORPORASI TERHADAP KORBAN DALAM KASUS TINDAK PIDANA LINGKUNGAN HIDUP. 5(2), 154-169.

Yatini. (2019). REFORMULASI KONSTRUKSI PIDANA DALAM MENJERAT PELAKU TINDAK PIDANA KORPORASI. Pasca Sarjana Hukum UNS, VII, 144-152.

Artikel Internet:

Badan Pusat Statistik. (2021). Ekonomi Indonesia Turun Sebesar 2,07 Persen (c-to-c). Badan Pusat Statistik. https://www.bps.go.id/pressrelease/2021/02/05/1811/ekonomi-indonesia2020-turun-sebesar-2-07-persen--c-to-c-.html

Kompas. (2021). Deretan Kasus Pungli Bansos. Kompas.Com. https:// megapolitan.kompas.com/read/2021/08/03/18561921/deretan-kasus-punglibansos-oknum-diduga-kutip-puluhan-hingga-ratusan?page $=$ all

Liputan 6. (2021). Korupsi Bansos Covid-19. Liputan6.Com. https:// www.liputan6.com/regional/read/4659573/korupsi-bansos-covid-19-bendaharadinsos-bandung-barat-disebut-minta-persenan-dan-jatah-miras

Nasional, K. P. C.-19 dan P. E. (2021). Peta Sebaran Covid-19. Indonesia. https://covid19.go.id/ peta-sebaran-covid19

World Health Organization. (2020). Timeline of WHO. WHO. https://www.who.int/emergencies/diseases/novel-coronavirus-2019/interactive- 
timeline\#!

Peraturan Perundang-Undangan:

Jurnal Yustika Vol.24 No. 01, Jul 2021

Halaman | 13 Tipologi Penindakan Kejahatan Korporasi Dalam Korupsi Dana Bantuan Pandemi Covid-19

Michelle Kristina
Keppres No 12 Tahun 2020 Tentang Penetapan Bencana Nonalam Penyebaran Corona Virus Disease 2019 Sebagai Bencana Nasional, (2020).

Peraturan Mahkamah Agung, Peraturan Mahkamah Agung No. 13 Tahun 2016, (2016).

Peraturan Pemerintah Nomor 21 Tahun 2020 tentang Pembatasan Sosial Berskala Besar Dalam Rangka Percepatan Penanganan Corona Virus Disease 2019 (COVID-19)

Putusan Nomor: 8/Pid.Sus-Tpk/2021/PN.Jkt.Pst, (2021).

Undang-Undang Nomor 24 Tahun 2007 tentang Penanggulangan Bencana, 634 (2007).

Undang-Undang Nomor 31 Tahun 1999 jo. Undang-Undang Nomor 20 Tahun 2001 tentang Pemberantasan Tindak Pidana Korupsi 